\title{
Cosmopolitan Jurisdiction and the National Interest
}

Cedric Ryngaert

The Oxford Handbook of Jurisdiction in International Law

Edited by Stephen Allen, Daniel Costelloe, Malgosia Fitzmaurice, Paul Gragl, and Edward Guntrip

Print Publication Date: Aug 2019 Subject: Law, International Law

Online Publication Date: Oct 2019 DOI: 10.1093/law/9780198786146.003.0010

\section{Abstract and Keywords}

This chapter explores the exercise of jurisdiction in the common interest. Drawing on realism and actual practice, it is posited that the exercise of jurisdiction in the common interest is unlikely unless the state has a nexus to the situation subject to regulation. The presence of a nexus may in fact serve to allocate jurisdictional authority and responsibility and encourage action in the common interest. In practice, cosmopolitan jurisdiction is hardly exercised. Scarce resources, fear of retaliation or reciprocity, and lack of local interest in global issues may cause states to forego assertions of cosmopolitan jurisdiction, unless a 'national interest' can be identified. The chapter then considers the actual practice of universal criminal jurisdiction.

Keywords: international courts, international tribunals, jurisdiction, statehood, jurisdiction of states, organs of states

I. Allocating the Exercise of Jurisdiction 212

II. Cosmopolitan Jurisdiction and the National Interest 218

III. Universal Criminal Jurisdiction: An Empirical and Normative Inquiry into National Interests 222

IV. Concluding Observations 226

(p. 210) THE law of jurisdiction may seem to be inherently conservative. Its foundational principles of territoriality and state sovereignty-in fact, the principles on which the positivist, modern conception of international law itself is based ${ }^{1}$-appear to be anathema to the development of a more progressive, cosmopolitan agenda based on furthering common interests of the international community. ${ }^{2}$ In the face of glaring global governance failures, such as climate change and persistent human rights abuses, the exercise of jurisdiction in the common interest may, however, increasingly be called for. On closer inspection, nevertheless, even if the pedigree of the law of jurisdiction does not augur well for the exercise of jurisdiction in the common interest, the principles of jurisdiction may, somewhat surprisingly perhaps, be sufficiently capacious to accommodate the champions of cosmopolitanism. ${ }^{3}$ For one thing, the principle of territoriality-although originally devised to keep territorial sovereigns apart in line with the billiard-ball view of classic inter- 


\section{Cosmopolitan Jurisdiction and the National Interest}

national law-has been moulded to further the common interest, as states have considered even tenuous territorial connections as sufficient to justify their jurisdictional assertions. ${ }^{4}$ For another, the existence of universal criminal jurisdiction over (p. 211) core crimes against international law has been hailed as evidence of rising cosmopolitan solidarity among states and communities, ${ }^{5}$ jurisdictional solidarity which in future may possibly also extend to other offences. ${ }^{6}$

While some existing principles of jurisdiction may well accommodate the exercise of jurisdiction in the common interest, it would nonetheless be intellectually dishonest to dismiss the objection that such jurisdiction is in reality not, or seldom, exercised. If that objection is valid, and states are indeed not able and willing to act as jurisdictional agents of the international community, cosmopolitanism will remain dead letter. ${ }^{7}$ This chapter examines the variables that may determine the exercise of jurisdiction in the common interest. Its methodology is in the first place hermeneutical. It inquires what explanatory variables determine the dependent variable of the (non-)exercise of jurisdiction in the common interest, based on actual jurisdictional practice of states (and the European Union). However, the chapter's approach is also normative, where it seeks to justify particular interestbased practices of jurisdiction, or recommends reform. Ultimately, this chapter is a reflective and practically informed piece of doctrinal work.

Drawing on realism and actual practice ${ }^{8}$ it is posited that the exercise of jurisdiction in the common interest is unlikely unless the state has a nexus to the situation subject to (p. 212) regulation. The presence of a nexus may in fact serve to allocate jurisdictional authority and responsibility, and encourage action in the common interest. In practice, however, because the exercise of jurisdiction under international law is in principle discretionary, there is no guarantee that the state to whom jurisdiction is allocated will also assume it. As such, non-exercise of jurisdiction may have detrimental effects for global justice and global welfare, and therefore a second-order jurisdictional authority for 'bystander' (i.e. less closely connected) states may be called for (Section I). Nevertheless, realistically, bystander states are only likely to exercise 'cosmopolitan' jurisdiction if this also serves their national interests (Section II). It is argued that this limitation of cosmopolitan action need not be regrettable. Instead, it could, in appropriate circumstances, be justified from a normative perspective. The contribution discusses the variables determining the (non-)exercise of universal criminal jurisdiction in particular to support the argument that the exercise of universal jurisdiction is both empirically and normatively dependent on the presence of a national interest (Section III).

\section{Allocating the Exercise of Jurisdiction}

Rational choice theorists of international relations and international law would posit that the taking of state action is a function of the maximization of national welfare. ${ }^{9}$ On that basis, some of them may all but close the door to jurisdiction in the common interest. ${ }^{10}$ It may however be entirely rational for a state to exercise its jurisdiction, also if this turns out to be in the common interest, when a state nexus is initially present. ${ }^{11}$ The presence 


\section{Cosmopolitan Jurisdiction and the National Interest}

(p. 213) of a 'nexus', however constructed, ${ }^{12}$ ordinarily points to the presence of an interest of the state. This logically renders the exercise of jurisdiction more likely. ${ }^{13}$

In fact, using 'nexus' may increase the prevalence of jurisdictional action in the common interest as it goes some way to allocate responsibility: it circumscribes and thus defines the circle of actors competent to take action. If, in contrast, one were to promote a version of non-nexus-based, universal, cosmopolitan jurisdiction, no one may take action at all. The irony is apparent. Such jurisdiction may have been designed to address multilateral free-rider behaviour, but comes with its own free-rider problems: making everyone responsible to tackle a problem, may in practice be a recipe for doing nothing. Indeed, social psychologists have experimentally proved that group size has an impact on the likelihood that people help others in a state of emergency. ${ }^{14}$

The prosecution, or rather non-prosecution, of piracy is instructive in this respect. Under international law, every state has the right to arrest and prosecute pirates under the universality principle, for such pirates are considered to be hostes humani generis; they threaten the community of states at large. In practice, however, universal jurisdiction over piracy is hardly exercised. Even when patrolling vessels-for instance, off the coast of Somalia-come across pirates and arrest them, they are likely not to prosecute them, in particular not if no merchant vessel flying the flag of the intervening state has been attacked or threatened with attack. Even when a national interest is involved, (p. 214) patrolling vessels are likely to either release pirates after catching them, or turn them over to another state-notably Kenya, which operates anti-piracy courts sponsored by the international community-rather than to their own prosecutorial authorities. This may be so for a variety of reasons. Bystander states may not have national laws allowing for piracy prosecution, ${ }^{15}$ and even if they have them, prosecution in the arresting state's own courts may be far too costly, and unsuccessful prosecution may well cause the pirate to seek asylum in the bystander state, which, by virtue of the principle of non-refoulement, may be prevented from sending him back to his home state. ${ }^{16}$ Possibly most importantly, states may just reason that it does not increase national welfare-rather on the contrary-to prosecute a foreign pirate who has hijacked a foreign ship with foreign crew. ${ }^{17}$ Kontorovich and Art have succinctly put this conundrum as follows: 'perhaps the most obvious reason for the lack of universal jurisdiction is the fact that it is universal'. ${ }^{18}$ Or as Kontorovich argued in another publication: in economic terms, universal jurisdiction transforms claims 'into a global common resource, preventing several ownership', which in turn prevents them from being 'put to their social highest valued use'-thus ultimately decreasing global welfare. ${ }^{19}$ In other words, universal jurisdiction may lead states to shirk their cosmopolitan responsibilities: their reasoning that other states should also bear the enforcement burden may ultimately yield the outcome that no state takes action. ${ }^{20}$

Relying on 'nexus', instead, could serve as an incentive for states to assume their responsibility. Indeed, the immediacy of the encounter produced by the nexus of an act, actor, or situation with the state may bring to its attention how this jeopardizes common as well as local interests, and create opportunities for remedial action through the exercise of juris- 


\section{Cosmopolitan Jurisdiction and the National Interest}

diction. ${ }^{21}$ At the same time, from a positivist international law perspective, 'nexus' allows states to err on the safe side of jurisdictional caution: jurisdictional claims (p. 215) that are grounded on a nexus with the state, in particular a territorial nexus, are much more likely to pass the legality test. In addition, they provide some legal certainty to individuals and operators who can anticipate falling within the ambit of the law if their conduct has a nexus with the state. ${ }^{22}$

From an enforcement point of view, the law of jurisdiction may have to be geared towards facilitating nexus-based jurisdiction. This may even normatively imply that bystander states-which have no or only a weak nexus to the case-should, if possible, refrain from exercising jurisdiction. Indeed, too readily assuming such jurisdiction may give rise to free-rider behaviour of states that do have a strong connection to the case: the availability of remedies elsewhere may discourage them from assuming their own jurisdiction. For instance, in the Kiobel litigation arising under the US Alien Tort Statute (ATS) before the US Supreme Court, the United Kingdom and the Netherlands argued in their amicus brief that the exercise of universal civil jurisdiction by a bystander state would give states with a nexus to the case 'reason to downplay and even ignore their own international human rights law obligations' and that '[t]hey will also not come under pressure to provide a remedy, and indeed prevent abuses, if plaintiffs have recourse to redress elsewhere'. ${ }^{23}$ Possibly swayed by these arguments, the Court eventually went on to reject a broad jurisdictional construction of the Alien Tort Statute, ${ }^{24}$ a decision that, regardless of the technicalities, may have been informed by the concern that US courts may become global human rights enforcers undercutting the responsibility of other states. Indeed, holding that it was not the duty of the United States to be the 'custos morum of the entire world', the Court implied that the US legal system should not spend precious judicial resources that other, more closely connected, free-riding states may be unwilling to spend. ${ }^{25}$ The same anti-imperialist concern ${ }^{26}$ is oozed by the earlier US Supreme Court decision in Empagran (2004), which dismissed a claim brought by foreign victims of a worldwide vitamins cartel in respect of foreign harm. ${ }^{27}$ Arguably, opening up US courts to such a claim would come down to the United States bearing the international antitrust enforcement burden alone and becoming the 'global antitrust (p. 216) cop'. ${ }^{28}$ As a result, foreign plaintiffs' home states may just free-ride on US investigatory and litigation efforts.

The argument thus is that, in order to prevent free-riding by more closely connected states, it may be advisable to allocate jurisdiction to states with a convincing nexus to a situation, and for more loosely connected states to refrain from exercising their 'cosmopolitan' jurisdiction. From a normative perspective, this nexus-based allocation principle also encourages regulatory and democratic learning, local ownership, and-as far as localized (human rights) wrongs are concerned-facilitates transnational justice efforts steered by the directly affected societies rather than by distant strangers. ${ }^{29}$

Allocating jurisdiction to states with a (strong) nexus and disavowing the jurisdiction of prima facie less-concerned bystander states, along the lines sketched here, sounds attractive. Unfortunately, however, it falls short in practice. This is mainly because the law of jurisdiction is largely based on discretionary authority rather than obligation. ${ }^{30}$ 


\section{Cosmopolitan Jurisdiction and the National Interest}

Consequently, jurisdictional deference by one state does not always result in the assumption of jurisdiction by another state, even if the facts call for regulatory intervention of some sort. Abstract concerns over free-riding behaviour flowing from too-ready cosmopolitan assertions of jurisdiction may then result in the absence of any state exercising jurisdiction, to the detriment of the specific interests of individual victims of injustice, or of the global commons. The above-mentioned cases of Kiobel and Empagran demonstrate this well. The Court's declining of jurisdiction in Empagran left the victims of the vitamins cartel out in the cold, as they could not recover their damages anywhere, their local courts being inaccessible. ${ }^{31}$ From a global justice perspective, this outcome is not satisfactory. Instead, the Court could have heeded the argument advanced in an amicus brief drafted by two economists, who called on the Court to take into account global deterrence in US antitrust litigation, and thus to provide a remedy for antitrust harm suffered in foreign transactions. ${ }^{32}$ Also, Kiobel shows that concerns over foreign nations free-riding on the efforts of one state risks leaving individual plaintiffs without any remedies. ${ }^{33}$ The aforementioned amicus brief of the United Kingdom and the (p. 217) Netherlands in fact appears to be a classic example of states' own narrowly conceived national economic interests masquerading as global welfare arguments. Both states obviously wished to shield Shell, an Anglo-Dutch corporation, from liability in US courts, rather than to allocate responsibility among states. US litigation under the universality principle did not diminish the opportunities or incentives for the United Kingdom or the Netherlands to assume their own legal responsibility with respect to Shell's activities in Nigeria, but both states arguably never had an interest in doing so in the first place. ${ }^{34}$ On the contrary, litigation in bystander state courts could set in motion processes of broader social and legal reform in the more closely connected states by exposing patterns of misconduct. For instance, the 'Pinochet effect' in Latin America-the impact of the Spanish indictment, under the universality principle, of the former Chilean dictator on criminal proceedings against torturers in Chile and elsewhere in South America-has been well-documented. ${ }^{35}$ Thus, the initial exercise of cosmopolitan jurisdiction, rather than encouraging free-riding, may prevent future free-riding in that strengthened local jurisdictional capacity reduces reliance on foreign jurisdiction. For this reason, when the exercise of 'local' jurisdiction is unlikely, bystander states showing only a weaker nexus may want to give 'temporary' protection with a view to spurring other states into action in the global interest. ${ }^{36}$ This could be defined as positive jurisdictional subsidiarity or complementarity. ${ }^{37}$

\section{(p. 218) II. Cosmopolitan Jurisdiction and the Na- tional Interest}

In the first section, two arguments have been made. It has been submitted that states are, realistically, more likely to exercise jurisdiction in the global interest when they have a nexus to the situation at hand. At the same time, a warning was sounded not to draw the normative inference that the presence of a strong nexus is a necessary condition for the legitimate exercise of jurisdiction. Where global and individual justice are jeopardized, bystander states sporting only a weak nexus should be allowed to exercise complemen- 


\section{Cosmopolitan Jurisdiction and the National Interest}

tary or subsidiary jurisdiction. However, for the actual exercise of jurisdiction, whether or not a nexus (typically a territorial one) is present, is ultimately of lesser relevance than the presence of a national interest or a national goal. ${ }^{38}$ The realist paradigm indeed has it that states will follow a particular course of conduct if they perceive such a course to be in their-or their constituents'-interest, however defined. ${ }^{39}$ Realist approaches normally limit the space for cosmopolitan action, as such action by bystander states is not likely to further the latter's interests. The outcomes in the aforementioned Kiobel and Empagran cases, for instance, can be explained by a concern that a more cosmopolitan jurisdictional outlook may diminish, or at least not further 'the national interest'. ${ }^{40}$ These cases are concrete instantiations of a more general and rather well-entrenched jurisdictional realism that is distrustful of cosmopolitanism on the ground that rulers of states, at least in liberal-democratic states, are beholden to their voters, who may punish them in case they prioritize the interests of others over theirs. ${ }^{41}$ In theory, state rulers (p. 219) will thus be forced to abandon a cosmopolitan discourse, or when using it do so strategically to advance their voters' interests. Even when harbouring cosmopolitan sentiments, states may be unwilling to shoulder the cosmopolitan burden alone. Exercising unilateral jurisdiction may, as argued here, cause other states to free-ride on the former's efforts, or invite protest against jurisdictional overreach, inducing states in turn to scale back their efforts. This is a classic collective-action problem.

A perception that the national interest is not at stake; ${ }^{42}$ fear of upsetting foreign nations and thus inviting retaliatory action; ${ }^{43}$ or concerns over judicial complications, ${ }^{44}$ costs, and wasting scarce national resources all militate against cosmopolitan action. Research into the actual exercise of universal criminal jurisdiction, for instance, has shown that such jurisdiction is normally only exercised when the stakes are not very high-for example, over lower-ranking perpetrators, in which case the risk of upsetting foreign nations is limited. ${ }^{45}$ In addition, resource and capacity problems have undoubtedly informed decisions not to prosecute, ${ }^{46}$ as domestic resources are more likely to be (p. 220) spent to address domestic problems. In the end, prosecutors are unlikely to take action in the global interest when there is not at least a national interest at stake, as also evidenced by a statement of the chief prosecutor of Hamburg, Germany, regarding the prosecution of piracy: '[T]he German judicial system cannot, and should not, act as World Police. Active prosecution measures will only be initiated if the German State has a particular, well-defined interest. ${ }^{47}$ In civil cases, the courts have also often construed broad jurisdictional mandates restrictively, and ultimately emphasized the state's national interest. The vagaries of the Alien Tort Statute illustrate this well. On its face, this US Statute is a cosmopolitan's dream in that it appears to confer universal tort jurisdiction over US federal courts in respect of violations of international law and, after its 'rediscovery' in 1980, some US courts were indeed willing to offer a remedy to foreign victims in respect of foreign harm committed by foreign perpetrators. ${ }^{48}$ However, ultimately, in Kiobel, the Supreme Court limited the jurisdictional scope of the ATS to claims 'touching and concerning' the United States 'with sufficient force'. ${ }^{49}$ Even the minority judges in Kiobel were of the view that the Alien Tort Statute should be interpreted as 'providing jurisdiction only where distinct American interests are at issue'. ${ }^{50}$ 


\section{Cosmopolitan Jurisdiction and the National Interest}

Admittedly, to the extent that cosmopolitan values are seen as reflecting domestic values, institutions, and interests, the former may actually strengthen the latter, and thus open up a space for cosmopolitan action. In international relations, this is termed 'second image reversed'. ${ }^{51}$ When states have had a strong influence on the making of international law, the odds of domestic 'cosmopolitan' enforcement of international law in such states may be higher. ${ }^{52}$ And even where states and their officials consider the 'national interest' to be their guiding light, they need not understand this as a parochial concept per se at loggerheads with cosmopolitan action. For instance, the aforementioned minority judges in Kiobel were in favour of the exercise of jurisdiction in case the defendant's conduct substantially and adversely affects an important American national (p. 221) interest, including a distinct interest in preventing the United States from becoming a safe harbour (free of civil as well as criminal liability) for a torturer or other common enemy of mankind. ${ }^{53}$ As international criminals are unlikely to repeat their crimes on US soil in the absence of a context propitious to their commission, this scenario actually has cosmopolitan overtones. It is arguably in the interest of every state, including the United States, to see to it that justice is done regarding international crimes, as such crimes affect the international community and all its constituent members. ${ }^{54} \mathrm{~A}$ similar view can be found in the 2014 decision of the South African Constitutional Court in the Zimbabwe case, in which it ruled that '[g]iven the international and heinous nature of the crime of torture, South Africa has a substantial connection to it' ${ }^{55}$ This appears to be jurisdictional cosmopolitanism in its purest form: international crimes are considered as having a nexus with every state, and every community interest is considered as a national interest. The South African decision is a fine example of how unconnected states, in spite of realist considerations militating against jurisdictional cosmopolitanism, have assumed their responsibility, especially by exercising universal jurisdiction over gross human rights violations. ${ }^{56}$ Or as Uta Kohl has observed, bystander states may want to act in such a cosmopolitan fashion 'perhaps simply because it is the right thing to do'. ${ }^{57}$

This idea that states should exercise universal jurisdiction because it is morally appropriate may be compelling. However, states exercising 'cosmopolitan' jurisdiction rarely do so only because it is the right thing to do, but rather because it is (also) in their national interest. Below in Section III, this is illustrated by the exercise of universal criminal jurisdiction. The analysis does not limit itself to observing empirical patterns, however. It is also argued that sound 'national interest'-based reasoning may be normatively preferable over abstract cosmopolitanism, as it provides reasons for action that strengthen a polity's identity and values. 


\section{(p. 222) III. Universal Criminal Jurisdiction: An Em- pirical and Normative Inquiry into National In- terests}

A vast pool of cases potentially qualify for universal jurisdiction. However, a specific pattern may be discerned in the kind of cases that are actually brought. Such cases, while formally brought by an independent public prosecutor, typically result from pressure brought to bear on prosecutors by victim communities that have sought refuge in a bystander state. Thus, Frédéric Mégret has pointed out that universal jurisdiction 'is almost never exercised in a pure supranationalist void by states "sacrificing themselves" for the global public good', but instead 'almost always follows existing patterns of transnational interaction between states'; in particular, 'victim diasporas' are 'the crucial variable in understanding the evolving practice of [universal jurisdiction] as it actually unfolds in reality'. ${ }^{58}$ The cases brought in Spain under the universality principle against alleged human rights offenders from Latin America, or cases brought in Belgium or France against offenders from Rwanda could thus be better comprehended contextually. ${ }^{59}$

This empirical reality of universal jurisdiction being exercised at the behest of victim diasporas can, according to Mégret, even be considered as normatively defensible to the extent that it becomes an 'integral part of the normal process of welcoming refugees' and contributes to the strengthening of a state's multicultural society, in which newcomers' citizenship is a function of the host state demonstrating empathy and solidarity. ${ }^{60}$ Thus, by exercising universal jurisdiction, states may not (just) show international solidarity, (p. 223) but also, and more so in fact, vindicate their own national interest in building a stable society in which immigrants feel welcome and integrated.

Integrating immigrants from diasporas is, however, only one national interest that can be served by the exercise of universal jurisdiction. Arguably, any national interest that is grounded in political community and identity could qualify as an empirical trigger for the exercise of 'common interest'-based jurisdiction, as well as a normative reason for action. Thus, as Itamar Mann has noted, the Jerusalem District Court in Eichmann, when it established its universal jurisdiction, acted not only as a 'Court of Humanity', vindicating the interests of the international community pursuant to the universality principle, but also as a 'Court of Violence', exercising the state's (i.e. Israel's) right to punish Eichmann on the grounds of the 'special connection the State of Israel has with such crimes, seeing that the People of Israel-the Jewish People-constituted the target and the victim of most of the crimes in question'. ${ }^{61}$

The question then arises: what national political interests appropriately trigger the exercise of universal jurisdiction? ${ }^{62}$ Mann refrains from giving an all-encompassing definition of 'appropriateness', but still, the examples which he gives of appropriate and inappropriate interests undergirding actual prosecutions give some guidance. Thus, Kenyan prosecutors may be justified in prosecuting Somali pirates under the universality principle insofar as piracy adversely affects Kenya's access to waterways. In contrast, insofar as 


\section{Cosmopolitan Jurisdiction and the National Interest}

these prosecutions may have been outsourced by Western states unwilling to shoulder the jurisdictional burden and instead paying other bystander states to prosecute the pirates on the basis of universal jurisdiction, questions as to the appropriateness of these prosecutions can be raised. ${ }^{63}$ Mann voices similar concerns regarding the appropriateness of Belgium's issuance of a warrant for the arrest of then Minister of Foreign Affairs of the Democratic Republic of the Congo, Abdoulaye Yerodia (2000), on charges of incitement to genocide, a crime amenable to universal jurisdiction, even in absentia pursuant to Belgian law applicable at the time (a warrant which sparked the Arrest Warrant case before the International Court of Justice (ICJ)). ${ }^{64}$ Echoing the separate opinion of ICJ Judge ad hoc Bula-Bula in the Arrest Warrant case, ${ }^{65}$ as well as David Luban's writings on crimes against humanity, ${ }^{66}$ Mann suggests that Belgium's prosecution should be precluded because of Belgium's 'bloody history' as the former colonial power in the Congo. ${ }^{67}$ That former colonizers have no 'moral right' to exercise universal criminal jurisdiction over former colonies has also informed the African (p. 224) Union's position on universal jurisdiction, ${ }^{68}$ as well as on the International Criminal Court (ICC) for that matter. ${ }^{69}$

The latter position is understandable from the perspective of (or a variation of) the 'clean hands' doctrine. ${ }^{70}$ Nonetheless, without wanting to press the argument too far, it is debatable whether Western states should perforce be precluded from sitting in judgment of heinous crimes committed in their former colonies, in light of transgressions committed at the time. Precluding Western states' reliance on universality may in fact foreclose valuable opportunities for the exercise of universal jurisdiction, as large diaspora communities-the actors precisely triggering universal jurisdiction-live on the territory of their former colonial masters. In fact, it could be argued that precisely because Western states have historically oppressed colonial peoples, with all the attendant consequences, such as a legacy of weak governance and armed conflict, they have a moral interest in atoning for their past sins by assisting their former colonial possessions, including by exercising universal jurisdiction over crimes committed by individuals in the latter. Such prosecutions under the universality principle may not only contribute to the entrenchment of accountability and the rule of law in former colonies. They also serve the purpose of reconstituting the polity of the former colonial oppressor as a polity that no longer defines itself as a victimizer, but as an emancipator of those victimized by the governance gaps left when the colonial power departed. ${ }^{71}$

(p. 225) The change in national identity resulting from former colonial powers' prosecutions under the universality principle could well be defined as an appropriate national interest, and may have informed actual jurisdictional practices. Bystander states' assumption of a role, on the basis of the universality principle, as emancipator of foreign peoples may even be seen as a means to atone for purely domestic historical injustices, or pave the way for the prosecution (whether domestic or extraterritorial) of these injustices. Spain's universality-informed prosecutions of Latin American human rights violators are instructive in this regard. As Amy Ross has argued, Spain's engagement with the prosecution of the (alleged) genocide in Guatemala can chiefly be explained by 'Spain's own problematic regarding its failure to achieve justice for violations, the lack of accountability for crimes committed under Franco, and the persistence of silence and impunity'. ${ }^{72}$ This po-

Page 9 of 23

PRINTED FROM OXFORD HANDBOOKS ONLINE (www.oxfordhandbooks.com). (c Oxford University Press, 2018. All Rights Reserved. Under the terms of the licence agreement, an individual user may print out a PDF of a single chapter of a title in Oxford Handbooks Online for personal use (for details see Privacy Policy and Legal Notice). 


\section{Cosmopolitan Jurisdiction and the National Interest}

litical background-Spain's failure to come to terms with its own past-was brought into even starker relief after the adoption of a Historical Memory Law in 2007, which failed to fully break official silence on the crimes committed by the Franco regime. ${ }^{73}$ Eventually, in 2008, this emboldened Judge Baltasar Garzon of the Spanish National Court-who had earlier filed a warrant for the arrest of former Chilean Head of State Augusto Pinochetto order the exhumation of mass graves and to charge Franco-era figures, a step which, for that matter, led to his fall from grace. ${ }^{74}$

While 'appropriateness' could be construed broadly, as including the wish to atone, there are obviously assertions of universal jurisdiction that should be considered 'inappropriate'. Inappropriate assertions of jurisdiction lack civic character-for instance, because a prosecution under the universality principle has been brought with ulterior motives, such as to force regime change or isolate politically inconvenient figures. In that case, while a national interest may be present, the exercise of universal jurisdiction on which it is based may not be considered as appropriate. For instance, French Investigating Judge Bruguière's issuance in 2006 of warrants for the arrest of nine senior Rwandan officials of the Kagame regime for their alleged role in the shooting down of the Rwandan president's aircraft which triggered the 1994 Rwandan genocide, may be suspect, not just because it was technically based on the in absentia exercise of passive personality-based jurisdiction, but more importantly because of a lingering suspicion (p. 226) that France was somehow involved in the genocide, or at least did not do enough to prevent it. Because of France's possible complicity in the Rwandan genocide, France may not have come to the prosecution with clean hands, and thus the exercise of jurisdiction in the case should be considered inappropriate. ${ }^{75}$

\section{Concluding Observations}

Cosmopolitan, unilateral jurisdiction is jurisdiction exercised over conduct that shocks the conscience of mankind. Every state could be considered to have a nexus with such conduct, thus grounding a right, or even a moral imperative, to exercise (universal) jurisdiction, typically over international crimes, gross human rights violations, or environmental abuses. ${ }^{76}$ In practice, such pure cosmopolitan jurisdiction is hardly exercised. Scarce resources, fear of retaliation or reciprocity, and lack of local interest in global issues may cause states (legislators, regulators, and courts) to forego assertions of cosmopolitan jurisdiction, unless a 'national interest' can be identified. This is a relatively well-documented empirical phenomenon.

In this chapter, the actual practice of universal criminal jurisdiction in particular has been examined. It has been demonstrated that 'abstract' cosmopolitanism does not serve as an incentive to establish jurisdiction. ${ }^{77}$ Rather, this incentive is constituted by a more concrete nexus with the state, an 'encounter' of the state with victims of injustice, or an interest of the state. ${ }^{78}$ This idea need not be sobering. Instead, it points to the empowering, real-life possibilities of a state exercising jurisdiction in the common (p. 227) interest in ways that at the same time strengthen or reconstitute the territorially bounded political 


\section{Cosmopolitan Jurisdiction and the National Interest}

community which the state is supposed to serve, and to whose members (both nationals and non-nationals) it owes fiduciary obligations given the relational character of state sovereignty. ${ }^{79}$ Ultimately, the idea is a reflection of the very nature of international law, which oscillates between cosmopolitanism and parochialism, ${ }^{80}$ between the celestial and the physically immediate. ${ }^{81}$

\section{Notes:}

(*) The research which resulted in this chapter has been funded by the European Research Council under the Starting Grant Scheme (Proposal 336230-UNIJURIS) and the Dutch Organization for Scientific Research under the VIDI Scheme (No. 016.135.322). This chapter builds on the author's inaugural lecture given at Utrecht University on 30 March 2015 on the occasion of accepting the Chair of International Law.

(1) 1See for a problematization: Cedric Ryngaert, "Territory in the Law of Jurisdiction: Imagining Alternatives', Netherlands Yearbook of International Law 2016 (2017): 49-82.

(2) See on the common interest: Wolfgang Benedek et al. (eds.), The Common Interest in International Law (Antwerp: Intersentia, 2014).

(3) Cosmopolitanism is defined here as a notion that, because human beings are part of a global community, they have (moral) obligations towards each other, irrespective of geographic distance. See on cosmopolitanism e.g. Kwame Anthony Appiah, Cosmopolitanism in a World of Strangers (New York: W. W. Norton, 2007). I consider cosmopolitan action as largely interchangeable with action in the common interest, even if the former may be considered as slightly narrower than the latter. Indeed, cosmopolitanism has originally been concerned mainly with realizing the autonomy and dignity which human beings have in common (that was in any event the meaning of Kant's cosmopolitan law-for a more detailed analysis of the Kantian approach, see also Ch. 9 in this Handbook). In contrast, the interests of the international community may not be limited to human dignity, and pertain, for instance, also to the protection of the global commons, such as clean air, a stable climate, and sustainable fisheries. For a jurisdictional exploration: Cedric Ryngaert, 'Extraterritorial State Action in the Global Interest: The Promise of Unilateralism', in Mayaan Amir and Ruti Sela (eds.), Extraterritorialities in Occupied Worlds (New York: Punctum Books, 2016), 219-45.

(4) Cedric Ryngaert, 'Whither Territoriality? The European Union's Use of Territoriality to Set Norms with Universal Effects', in Cedric Ryngaert, Erik J. Molenaar, Sarah Nouwen, What's Wrong with International Law, Liber Amicorum Prof. A. H. A. Soons (Leiden: Brill, 2015), 436-48. See on how the European Union uses sometimes weak territorial connections to extend the reach of EU law: Joanne Scott, 'Extraterritoriality and Territorial Extension in EU Law', American Journal of Comparative Law 62 (2014): 87-126. See on the uselessness of territoriality, especially in a cyber-context, given the ubiquitous territorial connections of conduct in cyberspace: Dan Svantesson, 'A New Jurisprudential Framework for Jurisdiction: Beyond the Harvard Draft', American Journal of International Law 109 (2015): 69-74. Actual legal practice is rife with examples of a (territorial) nexus trig- 


\section{Cosmopolitan Jurisdiction and the National Interest}

gering jurisdiction in-what could be considered as-the common interest. Multiple states have exercised jurisdiction over vessels engaged in illegal, unreported, or unregulated fishing on the high seas-a major threat to global fish stocks-when such vessels dock in their ports, over which states normally exercise full territorial sovereignty. The European Union has regulated emissions from foreign aviation-emissions that contribute to global warming -insofar as they landed on, or departed from, EU aerodromes, i.e. EU territory. Directive 2008/101/EC of the European Parliament and of the Council of 19 November 2008 amending Directive 2003/87/EC so as to include aviation activities in the scheme for greenhouse gas emission allowance trading within the Community [2009] OJ L 8/3; Court of Justice of the JEU, Air Transport Association of America et al. v Secretary of State for Energy and Climate Change, judgment of 21 December 2011, para. 104. The United States has proved willing to establish jurisdiction, e.g. to tackle international corruption or drugs-trafficking, as soon as some aspect of a transnational activity has a connection with the United States, 'even if that aspect is fleeting and minor relative to the rest of the conduct comprising the claim'. Anthony J. Colangelo, 'What Is Extraterritorial Jurisdiction?', Cornell Law Review 99 (2014): 1303-52, 1306. However, on other occasions it has rejected jurisdiction where a nexus was clearly present. Cf. Morrison $v$ National Australia Bank, 561 US 247 (2010).

(5) Carly Nyst, 'Solidarity in a Disaggregated World: Universal Jurisdiction and the Evolution of Sovereignty', Journal of International Law and International Relations 8 (2012):

36-59, 58 (arguing that 'a study of universal jurisdiction complaints and prosecutions provides countless examples of the abridgement of traditional restrictions of territorial jurisdiction in the name of a community of humankind').

(6) The catalogue of offences amenable to such universal (connection-less) jurisdiction is, moreover, open-ended and expandable. E.g. genocide and war crimes committed in noninternational armed conflicts were initially not considered to be amenable to universal criminal jurisdiction, Notably, the Genocide Convention and the Geneva Conventions did not provide for universal jurisdiction over these offences. However, later state practice has confirmed universal jurisdiction over them. See for genocide e.g. Jorgic v Germany, App. No. 74613/01, ECtHR, judgment of 12 July 2007. See for war crimes committed in non-international armed conflicts: International Committee of the Red Cross, Customary International Humanitarian Law (Cambridge: Cambridge University Press, 2005), Rule 157. Also, the 1982 UN Convention on the Law of the Sea inserted a provision (Art. 218) allowing for the exercise of apparently universal port state jurisdiction over discharges.

(7) Roland Pierik and Wouter Werner, 'Can Cosmopolitanism Survive Institutionalization?', in Roland Pierik and Wouter Werner (eds.), Cosmopolitanism in Context: Perspectives from International Law and Political Theory (Cambridge: Cambridge University Press, 2010), 284.

(8) See on realism and international law e.g. Andrea Bianchi, 'International Relations and Social Science Methodologies', in Andrea Bianchi, International Law Theories: An Inquiry into Different Ways of Thinking (Oxford: Oxford University Press, 2016), ch. 6; Oliver 


\section{Cosmopolitan Jurisdiction and the National Interest}

Jütersonke, 'Realist Approaches to International Law', in Anne Orford and Florian Hoffman (eds.), The Oxford Handbook of the Theory of International Law (Oxford: Oxford University Press, 2016).

(9) Alexander Thompson, 'Applying Rational Choice Theory to International Law: The Promise and Pitfalls', Journal of Legal Studies 31 (2002): S285-S306.

(10) E.g. Jack Goldsmith and Stephen D. Krasner, 'The Limits of Idealism', Daedalus 132 (2003): 47-63.

(11) E.g. Rain Liivoja, 'The Criminal Jurisdiction of States: A Theoretical Primer', No Foundations 7 (2010): 25-58, 25 ('A State generally has little interest in spending its scarce resources on investigating offences that it has little or no connection to.'). Rational choice-inspired scholars have observed that individual or group morality informs state behaviour in relation to international law. See e.g. Jens David Ohlin, The Assault on International Law (Oxford: Oxford University Press, 2015), 103; Anne van Aaken, 'Behavioral International Law and Economics', Harvard International Law Journal 55 (2014): 421-81, 448 (drawing inspiration from behavioural economics, and describing altruistic behaviour of states on the basis of consumer preferences). In this article it is argued that the morally informed or altruistic exercise of jurisdiction is however conditional on the presence of a state connection or interest, which need however not be narrowly construed. See on conditional international law: Gregory Shaffer and Tom Ginsburg, 'The Empirical Turn in International Legal Scholarship', American Journal of International Law 106 (2012): 1-7.

(12) When exactly a transnational activity has a nexus with a state is not self-evident, but depends on what law-appliers consider as a relevant nexus. This means that transnational acts could sometimes rather artificially be 'located' within a particular state's territory. Colangelo (n. 4), 1323 ('[E]ven seemingly straightforward jurisdictional questions of geography often hinge on some predicate legal determination about where, exactly, one locates the relevant aspect or aspects of a claim or suit.'). See e.g. the US Supreme Court's principle that application of the presumption against extraterritoriality requires an analysis of the 'statutory focus'. In Morrison, for instance, the Court held that the relevant (securities law) statute's focus was not on fraudulent conduct but rather on the sale and purchase of securities. As the latter occurred abroad, there was no relevant nexus to the US, and hence no jurisdiction. Morrison v National Australia Bank (n. 4).

(13) However, the precise ambit of the legal norm applied may vary, depending on the strength of the nexus, or the nature of the norm. See Liivoja (n. 11), 36 (submitting that 'every individual norm possesses some sort of ambit'). Compare e.g. Morrison (considering fraudulent acts in the US producing effects abroad as not sufficient to find jurisdiction under US securities regulations) with Pasquantino $v$ United States, 544 US 349, 365 (2005) (finding jurisdiction over a wire fraud devised in the US but producing effects in Canada). Not, however, that the ambit of categories of norms may be laid down by law, e.g. in the general part of the criminal law, which typically considers territory to be the relevant nexus. 


\section{Cosmopolitan Jurisdiction and the National Interest}

(14) See for early work in social psychology: John M. Darley and Bibb Latané, 'Bystander Intervention in Emergencies: Diffusion of Responsibility', Journal of Personality and Social Psychology 8 (1968): 377-83; Mark R. Leary and Donelson R. Forsyth, 'Attributions of Responsibility for Collective Endeavors', Personality and Social Psychology Review 8 (1987): 167-88. See for more recent work: Karin E. Tobin, Melissa A. Davey, and Carl A. Latkin, 'Calling Emergency Medical Services during Drug Overdose: An Examination of Individual, Social and Setting Correlates', Addiction 100 (2005): 397-404; Christian Vaillancourt, Ian G. Stiell, and George A. Wells, 'Understanding and Improving Low Bystander CPR Rates: A Systematic Review of the Literature', Journal of the Canadian Association of Emergency Physicians 10 (2008): 51-65; Karl H. Teigen and Wibecke Brun, 'Responsibility Is Divisible by Two, but not by Three or Four: Judgments of Responsibility in Dyads and Groups', Social Cognition 29 (2011): 15-42.

(15) Yvonne Dutton, 'Maritime Piracy and the Impunity Gap: Insufficient National Laws or a Lack of Political Will?', Tulane Law Review 86 (2012): 1111-63, 1120.

(16) Emmanuel Obuah, 'Outsourcing the Prosecution of Somali Pirates to Kenya: A Failure of International Law, or a Response to Domestic Politics of States?', African Security Review 21 (2012): 40-61, 50.

(17) Milena Sterio, 'Piracy off the Coast of Somalia: The Argument for Piracy Prosecutions in the National Courts of Kenya, The Seychelles, and Mauritius', Amsterdam Law Forum 4 (2012): 104-23, 111 (wondering why the United Kingdom should pay for the exercise of universal jurisdiction on behalf of a Liberian vessel owned by a Dutch corporation and employing a Philippine crew).

(18) Eugene Kontorovich and Steven E. Art, 'An Empirical Examination of Universal Jurisdiction for Pirates', American Journal of International Law 104 (2010): 436-53, 453. From these authors' research it transpires that between 1998 and 2009, 1,158 pirate attacks on the high seas were reported. Only seventeen prosecutions were brought under the principle of such universal jurisdiction (i.e. only $1.47 \%$ of the attacks reported), even though all those attacks were subject to universality.

(19) Euegene Kontorovich, 'The Inefficiency of Universal Jurisdiction', University of Illinois Law Review 2008(1) (2008): 389-418, 395, arguing in respect of universal jurisdiction over piracy.

(20) See also Frédéric Mégret, "The "Elephant in the Room” in Debates about universal Jurisdiction: Diasporas, Duties of Hospitality, and the Constitution of the Political', Transnational Legal Theory 6 (2015): 89-116, 95.

(21) See on the ethics of encounter: Emmanuel Levinas, Totalité et Infini. Essai sur l'extériorité (The Hague: Martinus Nijhoff 1961).

(22) Cf. An Hertogen, 'Letting Lotus Bloom', European Journal of International Law 26 (2015): 901-26, 919 ('The territorial allocation of prescriptive jurisdiction provides certainty to individuals, who do not need to determine the nationality of those with whom

Page 14 of 23

PRINTED FROM OXFORD HANDBOOKS ONLINE (www.oxfordhandbooks.com). (C Oxford University Press, 2018. All Rights Reserved. Under the terms of the licence agreement, an individual user may print out a PDF of a single chapter of a title in Oxford Handbooks Online for personal use (for details see Privacy Policy and Legal Notice). 


\section{Cosmopolitan Jurisdiction and the National Interest}

they interact to determine which legal system governs their interaction.'). Hertogen argues against an overly strict interpretation of territoriality, however (at 920).

(23) Brief of the Governments of the Kingdom of the Netherlands and the United Kingdom of Great

Britain and Northern Ireland as Amici Curiae in Support of Neither Party, Kiobel v Royal Dutch Petroleum Co., 133 S. Ct 1659 (2013) (No. 10-1491), 25, https://

www.americanbar.org/content/dam/aba/publications/supreme_court_preview/briefs/ 10-1491_neutralamcunetherlands-uk-greatbritain-andirelandgovs.authcheckdam.pdf.

(24) Kiobel v Royal Dutch Petroleum Co., 133 S. Ct 1659 (2013) (applying the presumption against extraterritoriality).

(25) Ibid., 1668; and at 1669 quoting Morrison v National Australia Bank, 130 S. Ct 2869, 2878 (2010) (citing the 'presumption that United States law governs domestically but does not rule the world').

(26) See on territorialism as anti-imperialism: Jenny S. Martinez, 'New Territorialism and Old Territorialism', Cornell Law Review 99 (2014): 1387-414.

(27) F. Hoffmann-LaRoche Ltd v Empagran SA, 542 US 155, 159-65 (2004).

(28) Hannah Buxbaum, 'National Jurisdiction and Global Business Networks', Indiana Journal of Global Legal Studies 17 (2010): 165-81, 175 ('[T]he court retreated into its "natural" space of engagement. It did not really engage the substance of the plaintiffs' argument regarding global under-deterrence ...'). Formally speaking, the Court declined to exercise jurisdiction over separate foreign antitrust harm on the ground that the non-economic principle of non-intervention in the affairs of foreign states carried more weight. However, as there was little evidence of foreign nations taking issue with the US exercise of jurisdiction in the case, the Court in fact feared that foreign plaintiffs would flock to US courts if the Court would construe the geographical ambit of US antitrust law too widely.

(29) Cf. H. Moodrick-Khen, 'Revisiting Universal Jurisdiction: The Application of the Complementarity Principle by National Courts and Implications for Ex-Post Justice in the Syrian Civil War', Emory International Law Review 30 (2015): 261-311.

(30) See, however, on the shift from permission to duty: Alex Mills, 'Rethinking Jurisdiction in International Law', British Yearbook of International Law 84 (2014): 187-239.

(31) Ralf Michaels, 'Global Problems in Domestic Courts', in Sam Muller et al. (eds.), The Law of the Future and the Future of the Law (Oslo: Torkel Opsahl Academic EPublisher, 2011).

(32) Brief of Amici Curiae Economists JE Stiglitz and PR Orszag in Support of Respondents, F. Hoffmann-LaRoche v Empagran SA, 542 US 155 (2004) (No 03-724). 


\section{Cosmopolitan Jurisdiction and the National Interest}

(33) But see the civil case brought in early 2017 by Esther Kiobel against Shell in the Netherlands. See Het Financieele Dagblad, 'Nigeriaanse activiste daagt Shell voor rechter in Nederland', 13 January 2017. The Dutch case is however not exactly the same as the case brought in the United States. The latter concerned Shell's aiding and abetting of the Nigerian government's crushing of Ogoni resistance to oil development in the Niger River Delta, whereas the former only concerns Shell's complicity in the killing of Barinem Kiobel in 1995.

(34) Uta Kohl, 'Corporate Human Rights Accountability: The Objections of Western Governments to the Alien Tort Statute', International and Comparative Law Quarterly 63 (2014): 665-97, 684 ('States that have a connection with the dispute based on the nationality of the parent company (in Kiobel, the UK and the Netherlands) also have no real interest in holding the parent accountable for its or its subsidiary's behaviour abroad which injures people to whom they are not politically accountable.').

(35) Regina v Bow Street Metropolitan Stipendiary Magistrate, ex parte Pinochet Ugarte (No. 3),

[2000] 1 AC 147 (HL 1999). Naomi Roht-Arriaza, The Pinochet Effect: Transnational Justice in the Age of Human Rights (Philadelphia: University of Pennsylvania Press, 2006). See on the impact of Spanish universal jurisdiction on proceedings in Guatemala: Amy Ross, 'The Ríos Montt Case and Universal Jurisdiction', Journal of Genocide Research 18 (2016): 361-76. See on the impact of universal jurisdiction on proceedings in Rwanda: Leila Sadat, 'Transjudicial Dialogue and the Rwandan Genocide: Aspects of Antagonism and Complementarity', Leiden Journal of International Law 22 (2009): 543-62.

(36) The notion of 'temporary protection' has been developed in the field of migration law (e.g. UNHCR, Guidelines on Temporary Protection or Stay Arrangements, February 2014), where it is an exceptional measure to give protection to displaced persons unable to return to their country of origin. Likewise, states may exercise their universal jurisdiction to protect individuals who would otherwise go unprotected, in particular, to whom justice could not be served. Unlike in migration law, however, temporary protection in the law of jurisdiction may have a telos. As jurisdictional assertions regarding international crimes and gross human rights violations often implicitly pass judgement on a foreign state's policies and practices, they may be considered, or even intended as a lever to bring about structural change in the latter state. When such change has occurred, there may no longer be a need for the bystander state to exercise its jurisdiction.

(37) See on subsidiarity and universal jurisdiction: Cedric Ryngaert, 'Universal Jurisdiction over International Crimes and Gross Human Rights Violations: The Role of the Principle of Subsidiarity', The Global Community Yearbook of International Law and Jurisprudence (2015): 275-89. Note that the bystander state does not necessarily have the weaker nexus or interest than the territorial or national state. In this case, reliance on subsidiarity may make little sense. For instance, Mégret has criticized the subsidiarity principle on the ground that there is no unproblematic metric to compare whether prosecution of an international criminal in the territorial state is more important than in the 'by-

Page 16 of 23

PRINTED FROM OXFORD HANDBOOKS ONLINE (www.oxfordhandbooks.com). (c) Oxford University Press, 2018. All Rights Reserved. Under the terms of the licence agreement, an individual user may print out a PDF of a single chapter of a title in Oxford Handbooks Online for personal use (for details see Privacy Policy and Legal Notice). 


\section{Cosmopolitan Jurisdiction and the National Interest}

stander' state, especially not when the alleged criminal has fled to the bystander state where survivors of his crimes are also present. Mégret (n. 20), 105. Mégret's view should however not be viewed as an indictment of the subsidiarity principle, as the latter should arguably only counsel deference to the territorial or national state in case that state also has the stronger nexus to the situation, in the sense of suffering the most 'deviance from expressed norms of legal behaviour'. See on the latter Danielle Ireland-Piper, 'Extraterritorial Jurisdiction and the Cosmopolitan: A Double-Edged Sword' (2017) forthcoming (paper on file with the author), 13.

(38) E.g. M. Farbiarz, 'Extraterritorial Criminal Jurisdiction', Michigan Law Review 114 (2016): 507-57, 508 ('Over and over during the past few decades, the federal government has launched ambitious international prosecutions in the service of U.S. national security goals.') (emphasis added).

(39) In the most general sense, a national interest could be defined as the advantage or benefit enjoyed by a state (nation), or, alternatively as a common concern of a territorially delimited polity (state). See Oxford English Dictionary (online), definition of 'interest'.

(40) Kohl (n. 34), 685 (arguing that 'unconnected States have no obvious economic or political interest in monitoring these obligations towards foreign citizens to whom they are not legally or politically accountable').

(41) Jack Goldsmith and Eric Posner, The Limits of International Law (Oxford: Oxford University Press, 2005), 212. Non-democratic states may not be beholden to their voters and may consequently not incur any electoral punishments. Arguably, enlightened rulers of such states could more easily engage in jurisdictional cosmopolitanism. In reality, however, so as to remain in power, also such rulers may tend to espouse a nationalist discourse and to defend the national interest, sometimes more fiercely so than in democratic states. See e.g. on Chinese nationalism: Alastair Ian Johnston, 'Is Chinese Nationalism Rising? Evidence from Beijing', International Security 41 (2016/17): 7-43. In any event, there is no empirical evidence of non-democratic states exercising universal jurisdiction over core crimes against international law.

(42) Note that, rather exceptionally, outside a cosmopolitan context, even when a national interest is at stake and a jurisdictional grant is apparent, courts may for technical jurisdictional reasons not exercise jurisdiction. See e.g. Lindsay Farmer, "Territorial Jurisdiction and Criminalization', University of Toronto Law Journal 63 (2013): 225-46, 226-7, citing $R v$ Serva (1845), 1 Den 104, 169 ER 169 and $R v$ Keyn (1876-7), LR 2 Ex D 63, arguing that in these cases 'English courts declined jurisdiction in situations where it might easily have been claimed-and in the face of strong political demands', basing their reasoning 'on the analysis of a highly technical body of law'.

(43) It is observed that not exercising (extraterritorial) jurisdiction might under certain circumstances also lead to foreign protest. See e.g. the case of $R v$ Bernard (1858), $1 \mathrm{~F} \& \mathrm{~F}$ 240, in which an English court acquitted a man involved in a plot on the life of Napoleon 


\section{Cosmopolitan Jurisdiction and the National Interest}

III for reasons of uncertainty as to whether the man had committed a crime under English law. The acquittal led to French protests. Case cited in Farmer (n. 42).

(44) E.g. Helen L. Trouille, 'France, Universal Jurisdiction and Rwandan Génocidaires: The Simbikangwa Trial', Journal of International Criminal Justice 14 (2016): 195-217, 214 (describing how in a French universal jurisdiction case, '[t]he first two weeks of the trial were spent setting the context for the three judges and the jurors of a genocide that occurred 20 years previously, 7,000 kilometres away, in a country in which, in all probability, none of them had ever set foot'.) Note that in that very case universal jurisdiction was exercised and the accused was convicted.

(45) Máximo Langer, 'The Diplomacy of Universal Jurisdiction: The Political Branches and the Transnational Prosecution of International Crimes', American Journal of International Law 105 (2011): 1-49.

(46) E.g. when the South African Police Service considered itself unable to initiate an investigation into torture committed in Zimbabwe, citing practical problems in particular. Republic of South Africa Constitutional Court, National Commissioner of The South African Police Service v Southern African Human Rights Litigation Centre and Another (CCT 02/14) [2014] ZACC 30; 2015 (1) SA 315 (CC); 2015 (1) SACR 255 (CC) (30 October 2014), para. 15. The South African Constitutional Court acknowledged practicability as a legitimate limiting principle, averring at para. 64 that '[f]oremost amongst these [practical] considerations are whether the investigation is likely to lead to a prosecution and accordingly whether the alleged perpetrators are likely to be present in South Africa on their own or through an extradition request; the geographical proximity of South Africa to the place of the crime and the likelihood of the suspects being arrested for the purpose of prosecution; the prospects of gathering evidence which is needed to satisfy the elements of a crime; and the nature and the extent of the resources required for an effective investigation'.

(47) Cited in Kontorovich and Art (n. 18), 451. See also Nico Krisch, 'The Decay of Consent: International Law in an Age of Global Public Goods', American Journal of International Law 108 (2014): 1-40, 28 ('US courts do not see their role as solving problems of a global nature as such.').

(48) See e.g. Filártiga v Peña-Irala, 630 F 2d 876 (2d Cir. 1980); Kadic v Karadzic, 70 F 3d 232 (2d Cir. 1995).

(49) Kiobel v Royal Dutch Petroleum Co. (n. 24), 1669 ('[E]ven where the claims touch and concern the territory of the United States, they must do so with sufficient force to displace the presumption against extraterritorial application.').

(50) Ibid., 1674.

(51) Peter Gourevitch, 'The Second Image Reversed', International Organization 32 (1978): 881-912. This theory holds that domestic structures and institutions are the consequence of states' positions of relative power in international politics.

Page 18 of 23

PRINTED FROM OXFORD HANDBOOKS ONLINE (www.oxfordhandbooks.com). (c) Oxford University Press, 2018. All Rights Reserved. Under the terms of the licence agreement, an individual user may print out a PDF of a single chapter of a title in Oxford Handbooks Online for personal use (for details see Privacy Policy and Legal Notice). 


\section{Cosmopolitan Jurisdiction and the National Interest}

(52) See Lisa Conant, 'Whose Agents? The Interpretation of International Law in Domestic Courts', in Jeffrey L. Dunoff and Mark A. Pollack (eds.), Interdisciplinary Perspectives on International Law and International Relations: The State of the Art (Cambridge: Cambridge University Press, 2012), 394-420, 411-12.

(53) Kiobel v Royal Dutch Petroleum Co. (n. 24), 1674 (going on to find, however, that the impugned conduct and the parties did not have a sufficient nexus with the US under this test).

(54) Cf. ibid., 1675 (writing that in the Filartiga decision, '[j]urisdiction was deemed proper because the defendant's alleged conduct violated a well-established international law norm, and the suit vindicated our Nation's interest in not providing a safe harbor, free of damages claims, for those defendants who commit such conduct').

(55) Republic of South Africa Constitutional Court, National Commissioner of The South African Police Service v Southern African Human Rights Litigation Centre and Another (n. 46), para. 78 (adding that, hence, '[a]n investigation within the South African territory does not offend against the principle of non-intervention').

(56) In the South African case, the Constitutional Court, after confirming the cosmopolitan connection of the case with South Africa, eventually rejected the practical problems cited by the police, held that there was a reasonable possibility that the police would gather evidence that may satisfy the elements of the crime of torture, and subsequently ordered the police to investigate the complaint. In so doing, it confirmed that practical difficulties should not be used as an excuse for a failure to act in the global interest. Ibid.

(57) Kohl (n. 34), 685.

(58) Mégret (n. 20), 99.

(59) In the French case of Munyeshyaka, for instance, the accused-who was charged for his involvement in the 1994 Rwandan genocide-had sought refuge in France, where some of his victims also lived. On that ground, Sadat considered the exercise of universal jurisdiction to be not 'exorbitant'. See Sadat (n. 35), 558 (also noting that the presence requirement, used to trigger universal jurisdiction in France, 'served to insulate France from some of the political controversies surrounding the use of universal jurisdiction in cases with fewer connections to the forum'). Munyeshyaka was acquitted in 2014. For a description of the case, see Trial International, 'Wenceslas Munyeshyaka' (2016), https:// trialinternational.org/latest-post/wenceslas-munyeshyaka/. The presence of a victim diaspora (in the case of Rwandan victims of genocide present in France organized as the Collectif des Parties Civiles pour le Rwanda) is not the only explanatory variable for the exercise of universal jurisdiction in a particular case, however. It may happen that state authorities discover that a person may have committed international crimes in the context of investigations into another crime. The French case of Simbikangwa is instructive in this respect. This Rwandan genocide suspect had fled to the French Indian Ocean island 


\section{Cosmopolitan Jurisdiction and the National Interest}

of Mayotte, where his true identity was revealed in the context of an investigation into false identity documents. See Trouille (n. 44), 196.

(60) Mégret (n. 20), 108-14, e.g., stating (at 111) that 'the criminal law becomes a way of constituting the political'. From this perspective, the exercise of universal criminal jurisdiction can be regarded as benefiting the national interest (at 114) ('the exercise of U[niversal] J[urisdiction] should be seen not as a net liability for the state').

(61) Cited in Itamar Mann, 'The Dual Foundation of Universal Jurisdiction: Towards a Jurisprudence for the "Court of Critique" ', Transnational Legal Theory 1 (2010): 485-521, 503.

(62) Ibid., 517.

(63) Ibid., 519.

(64) Case Concerning the Arrest Warrant of 11 April 2000 (Democratic Republic of the Congo v Belgium) [2002] ICJ 1.

(65) Case Concerning the Arrest Warrant of 11 April 2000 (DRC v Belgium), Judgment of 14 February 2002, individual opinion Judge Bula-Bula. Note that the Court itself did not address the legality or appropriateness of the exercise of universal jurisdiction, limiting itself to the question of the international immunity ratione personae of an incumbent Minister of Foreign Affairs.

(66) David Luban, 'A Theory of Crimes Against Humanity', Yale Journal of International Law 29 (2004): 85-167.

(67) Mann (n. 61), 518.

(68) African Union Model Law on Universal Jurisdiction: an African Response to Western Prosecutions based on the Universality Principle (2012), http://www.ejiltalk.org/wp-content/uploads/2012/08/AU-draft-model-law-UJ-May-2012.pdf> last accessed 31 January 2018.

(69) See African Union Withdrawal Strategy Document, 12 January 2017, https:// www.hrw.org/sites/default/files/supporting_resources/

icc_withdrawal_strategy_jan._2017.pdf (calling for mass withdrawal from the ICC).

(70) Diversion of Water from the River Meuse (Netherlands v Belgium) [1937] PCIJ (Series A/B) No. 70, 4.

77. The 'clean hands' doctrine as applied by international courts stems from the common law of Equity (including the maxim 's/he who comes to Equity must do so with clean hands') and the closely related maxim in Roman law nullus commodum capere potest de iniuria sua propria. This doctrine prevents a state from arguing that the acts of another state is unfair if the complaining state has previously acted improperly. See Stephen M. 


\section{Cosmopolitan Jurisdiction and the National Interest}

Schwebel, 'Clean Hands Principle', in Rüdiger Wolfrum (ed.), The Max Planck Encyclopedia of Public International Law, 2nd edn (Oxford: Oxford University Press, 2013).

(71) Marxist scholarship and scholarship in the tradition of Third World Approaches to International Law (TWAIL) has been decidedly critical towards the exercise of universal criminal jurisdiction, on the grounds that it perpetuates Western hegemony. See Andrea Bianchi, International Law Theories: An Inquiry into Different Ways of Thinking (Oxford: Oxford University Press, 2016), 86 (discussing the law of jurisdiction, including universal jurisdiction). Also, scholarship in the critical legal studies tradition has drawn attention to the dark sides of at first sight well-meaning humanitarianism. See e.g. David Kennedy, The Dark Sides of Virtue: Reassessing International Humanitarianism (Princeton: Princeton University Press, 2005). Some of this scholarship may however be overly statist, and pay insufficient attention to the rights and interests of individuals oppressed by their own government, rather than Western governments. It is argued in this chapter that, under certain circumstances, jurisdictional action by Western states can emancipate such individuals by vindicating their rights. For TWAIL in relation to the protection of human rights, see Sara Seck, 'Conceptualizing the Home State Duty to Protect Human Rights', in Karin Buhman, Mette Morsing, and Lynn Roseberry (eds.), Corporate Social and Human Rights Responsibilities: Global Legal and Management Perspectives (Basingstoke: Palgrave Macmillan, 2010), 25-51. For TWAIL in relation to environmental harm caused by corporations, see Sara Seck, 'Transnational Business and Environmental Harm: A TWAIL Analysis of Home State Obligations', Trade, Law and Development 3 (2011): 164-202.

(72) Ross (n. 35), 367.

(73) Ley de Memoria Historica or Ley por la que se reconocen y amplian derechos y se establecen medidas en favor de quienes padecieron persecucion o violencia durante la Guerra Civil, Law 52/2007 of 16 December (Spain).

(74) Ross (n. 35), 369-70. Note that Argentine courts, in a remarkable turning of the tables, later invoked the universality principle to investigate the Franco regime's crimes. Associated Press in Madrid, 'Human Rights Abusers in Franco-era Spain Could Be Tried in Argentina', The Guardian, 2 November 2014, https://www.theguardian.com/world/ 2014/nov/02/buenos-aires-spain-franco-argentina. An Argentinian investigating judge issued arrest warrants against twenty former officials of the Franco era, but Spanish authorities refused to arrest the suspects, citing the statute of limitations and an amnesty law. Luciana Bertoia, 'Spain Rejects Franco-Era Extradition', Buenos Aires Herald, 26 April 2014, http://www.buenosairesherald.com/article/157940/spain-rejects-francoera-extradition.

(75) Sadat (n. 35), 562. Sadat added, however, that '[o]ne can also make a strong counterargument to the effect that if one disaggregates the notion of the "state", and a state has an independent judiciary, the unclean-hands doctrine should have no application'. It happened that the French investigating judges succeeding to Bruguière found that the missiles were found to be fired from positions controlled by the Rwandan Armed Forces, not by Kagame’s RPF. See Tanguy Berthemet, ‘Rwanda: les vérités gênantes des juges 


\section{Cosmopolitan Jurisdiction and the National Interest}

français', Le Figaro, 12 January 2012, http://www.lefigaro.fr/international/ 2012/01/12/01003-20120112ARTFIG00456-rwanda-les-verites-genantes-des-jugesfrancais.php. French proceedings regarding the attack were relaunched in 2016, however. See 'Rwanda: l'enquête sur l'attentat contre Habyarimana relancée en France', Le Parisien, 7 October 2016, http://www.leparisien.fr/international/rwanda-l-enquete-sur-l-attentat-contre-habyarimana-relancee-en-france-07-10-2016-6184261.php.

(76) See on the link between the erga omnes obligation to provide reparations for gross human rights violations and the right, or even duty, for states to exercise universal civil (tort) jurisdiction: Andreas Bucher, 'La Compétence universelle civile', Recueil des Cours de l’Académie de droit international de La Haye 372 (2014): 9-127.

(77) Mégret (n. 20), 115 (arguing that the forum state 'would tend to typically ignore more virtual assertions of in absentia jurisdiction that seem to be based largely on some quixotic concept of abstract justice not based on any meaningful encounter').

(78) See on hybrid motivations for states to exercise extraterritorial jurisdiction: IrelandPiper (n. 37), 10 ('Nation states exercise extraterritorial jurisdiction for three main reasons: first, because they are legally obliged to do so; second, because they are morally obliged to do so; and, third, because it suits their own political or economic agendas. These motivations are not exclusive of one another, and it is likely that all three are present in most exercises of extraterritorial jurisdiction.'). See also Pierik and Werner (n. 7), 286-7 (notions of cosmopolitan justice may foster the pursuit of what states perceive to be in their interest, drawing particular attention to the mixture of national security with imperial agendas).

(79) Evan Fox-Decent and Evan J. Criddle, Fiduciaries of Humanity: How International Law Constitutes Authority (Oxford: Oxford University Press, 2016), 13.

(80) Mortimer Sellers (ed.), Parochialism, Cosmopolitanism and the Foundations of International Law (Cambridge: Cambridge University Press, 2012). See Ireland-Piper (n. 37), 27 ('the exercise of extraterritorial jurisdiction provides a means by which states can reconcile parochialism with cosmopolitanism. It is a form of transnationalism: a hybrid creature born of both international and domestic law.').

(81) Geoff Gordon and Wouter Werner, 'Between the Dog and the Divine: Resistance and Conventionalism in Cosmopolitanism', Utrecht Law Review 13 (2017): 28-36.

\section{Cedric Ryngaert}

Cedric Ryngaert is Chair of Public International Law at Utrecht University. Among other publications, he authored Jurisdiction in International Law, 2nd edn (Oxford University Press, 2015) and Unilateral Jurisdiction and Global Values (Eleven, 2015), and co-edited with Math Noortmann and August Reinisch, Non-State Actors in International Law (Hart, 2015), Non-State Actor Responsibilities (Brill, 2015), and The In- 


\section{Cosmopolitan Jurisdiction and the National Interest}

ternational Prosecutor (Oxford University Press, 2012). For his work on jurisdiction, he received the Prix Henri Rolin (2012). 